three ASA members, one an ex officio member of the Board, the other(s) open. This would provide flexibility for insuring representation from varying constituencies (African, Afro-American, Women). It would also open the possibility of having Mrs. Robinson participate, if she were willing. Nominations to the committee might be made by any member of the ASA.

(3) How often it should be given. Annually, with the option of skipping a year in the absence of an appropriate, available candidate.

(4) Other points to consider: criteria for selection. The selectee ought (a) to display qualities of personality, and (b) be engaged in activity that befit the memory of Jim Robinson. On the first count, this would suggest a person who manifests love and concern for others. On the second count, certain kinds of activity stand out as particularly appropriate. These include activity related to:

(a) Strengthening friendship and cooperation between Africans and Americans.

(b) Working directly with Africans in developing human resources.

(c) Working to strengthen and enrich spiritual life.

(d) Building grassroots, voluntary, self-help associations.

Logical candidates might include, for example, members of Afro-American skill groups working in Africa, political figures such as Kenneth Kaunda, and little known individuals whose contributions seemed to stand in consonance with James Robinson's ideals. The list of attributes above should not be seen as excluding other considerations, and the selection committee should be given maximum latitude. But it does seem that such a committee should bear in mind those values and actions for which Jim Robinson most clearly stood.

ABSOLOM VILAKAZI

\title{
RESOLUTION ON GUINEA-BISSAU
}

[The resolution on Guinea-Bissau passed at the Sixteenth Annual Meeting (see p. 3) was sent to the State Department on November 7, 1973. The following is the text of the State Department's reply.]

December 3, 1973

\author{
Mr. James Duffy, Executive Secretary \\ African Studies Association \\ Shiffman Center, Room 218 \\ Brandeis University \\ Waltham, Massachusetts \\ Dear Mr. Duffy:
}

Secretary Kissinger has asked me to reply to your letter informing him of the resolution adopted by the African Studies Association conceming US policy toward Guinea-Bissau. We appreciate knowing the views of your members on this matter.

The US Government looks to the establishment of certain facts before it considers extending recognition to a new state. These facts include the effective control over a clearly-defined territory and population; an organized governmental administration of that territory; and a capacity to act effectively to conduct foreign relations and to fulfill international obligations. In Africa, these factual criteria have generally been met in the past following a peaceful transition to independence from colonial status through an agreement between the colonial power and representatives of the people of the territory concerned. However, under international law, even if the fe factual criteria are present, a state is not obligated to recognize another entity as a state.

In Portuguese Guinea, the facts suggest that the basic criteria for recognition have not been met. The best information we have indicates that the African Party for the Independence of Portuguese Guinea and Cape Verde (PAIGC), the group that has declared the existence of an independent state of Guinea-Bissau, does not control as much as one third of the territory in question. 
To recognize a new state, when claims to effective control are in dispute, would set a precedent whereby dissident and disaffected groups the world over could project their internal claims internationally by requesting recognition as sovereign states.

Because the US Government must take into account both the facts it possesses and the possibly far reaching implications of extending recognition to any new claimant to independence, we do not recognize the PAIGC claim of an independent Guinea-Bissau.

Sincerely,

CAROL G. LAISE

Assistant Secretary for Public Affairs

\section{GRANTS \& AWARDS}

The ROCKEFELLER and FORD FOUNDATIONS jointly announce the fourth year of a worldwide program of awards in support of research on population policy. Proposals for social, scientific, and legal research on population policy will again be accepted. In addition, this year projects in population policy research drawing on humanistic disciplines will be encouraged.

Suggested research areas include:

- Interaction of population variables and social, cultural, and humanistic concerns

- Interaction of population variables and economic policies

- Population distribution

- Interaction of population variables and law

There are no specific eligibility criteria, but demonstrated research ability, knowledge of population issues, and previous experience in this or a closely related field are likely to be minimally necessary for individuals to be competitive. Proposals must be research-oriented. The proposed research should begin in 1974 (on or after July 1) and be completed within two years. In no case will an award exceed $\$ 50,000$, and a grant of such magnitude will be rare under this program. There are no standardized application forms or procedures. Proposals must be received by January 15, 1974. Evaluation and selection will be prompt; awards will be announced in April 1974.

For further information regarding the format of applications, write to: The Rockefeller-Ford Program for Population Policy Research, The Rockefeller Foundation, 111 West 50th Street, New York, N.Y. 10020.

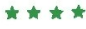

Professor MICHAEL M. HOROWITZ of the State University of New York at Binghamton, in association with the AGENCY FOR INTERNATIONAL DEVELOPMENT, has been invited to direct a series of studies in West Africa relating to economic and social development and to an analysis of the long-term sociological effects of the current drought in the Sahel. It is likely that several doctoral candidates or recent PhD's in Anthropology or related fields will be needed on the research team. Interested persons should submit a research project, following the NSF or NIMH format, complete with abstract, scope and significance of research, bibliography, proposed budget, time schedule and bio-data. Letters of recommendation, including a statement as to competence in oral French, and in any of the indigenous languages of the Sahel (Dioula, Bambara, Fulfulde, Songhoi, Hausa, Tamasheq, etc.) should be sent. The bulk of the study will probably be in Mali.

Write to: Professor M. M. Horowitz, Dept. of Anthropology, State University of New York, Binghamton, N.Y. 13901.

$\star \star \star \star$

The NATIONAL RESEARCH COUNCIL OF CANADA offers fellowships for $1974-75$ tenable in its 